of their fundamentals-photons, electrons and protons-feel, think, and-marvel ? Here, indeed, are matters worthy of wonder, real marvels which put the mysterious pullings of bell-wires and movements of coffins in their proper perspective. Hearsay statements concerning events the causes of which were not ascertained, especially when made by credulous people with a mystical bent, though not necessarily devoid of truth, are always suspect. Science has carried all before it in virtue of two golden rules, the one, to "take no man's word for it", the other to be economical in assumptions in accordance with the Law of Parsimony that causes are not to be multiplied beyond mental necessity-Entia non sunt multiplicanda praeter necessitatem.
Charles M. Beadnell.

\title{
A Compilation on Migrations
}

The Wandering Spirit :

a Studỳ of Human Migration. By Dr. Ragnar Numelin. Pp. xvi +375 . (London: Macmillan and Co., Ltd., 1937.) 20s. net.

$\mathrm{I}^{\mathrm{N}}$ his attempt to analyse the conditions and stimuli underlying human migrations, 'Đr. Numelin has cast his net over the entire world, and has considered human movements from Palæolithic times down to the present day. But, although his many citations show that the physical and social conditions promoting migration are very complex, his methods and criteria are too vague to yield satisfactory results.

Despite his strictures on their loose use by others, the author uses terms like migration, wandering and nomadism without clear distinction, and he often fails to discriminate between seasonal movements of all or part of a community within its territory and group migration from one territory to another. Much of the movement among foodgathering peoples, of which he cites many examples, is in its seasonal and cyclic character to be distinguished clearly from large-scale displacements under pressure of food shortage or human enemies, and the author does not seem to have considered the evidence for territorial fixation among these peoples. This confusion of seasonal movements and journeying with migration in the sense of permanent displacement also leads him to regard fishing peoples as more migratory than primitive collecting and hunting groups. There is much evidence from western North America and northeastern Asia, not mentioned by Dr. Numelin, which suggests that the contrary is more generally true.

Although a great deal of material is brought together in this volume, the use of sources is often very uncritical. The author frequently omits to mention or consider much recent work on peoples discussed, while general statements and assumptions of earlier writers are accepted as definitive. Assuming that remote linguistic relationships imply tribal migration between particular areas, he reaches improbable conclusions which are supported by no real evidence. The Iroquois, for example, are described as having migrated as coherent tribal groups from country west of the Mississippi, and the Navajo are brought to New Mexico from Alaska!

Dr. Numelin accepts creation myths as evidence of the origin and course of migrations of particular peoples, citing with approval for the Pueblo area the conclusions of Fewkes which, as later workers have shown, reduced the theory of historical migrations to absurdity. On the other hand, he does not refer to the more recent studies of Pueblo society by Kroeber, Parsons, and others, in which observed processes of fission and migration have been analysed. He gives numerous references to pilgrimages, trade journeys, and shifting of house and village site after death or pestilence, but does not discuss either the cumulative effects of such practices or their relation to group migration.

Although the discussion of "subsistence-geographical" conditions of migration, that is, the relation between the economy and the physical conditions at a particular place and time, is in general more satisfactory, and there are useful summaries of material on transhumance and other forms of seasonal migration in Europe, the evaluation of social and physiographical factors is rarely adequate. The author occasionally lapses into crude determinism. He refers frequently to mental qualities and uses the misleading term 'instinct', but does not present either a clear statement or cogent evidence concerning the part played by psychological factors.

This laborious piece of work has unfortunately been undertaken without either a clear formulation of the problems to be investigated or an adequate knowledge of recent methods and results in social anthropology. Dr. Numelin has not been very happily guided by those who revised his English text, for the writing is often unidiomatic, and his meaning is sometimes quite obscure.

Daryll Forde. 